the stream which flows near Phyöng Kang; the uniform depth of the lava is about 100 to I 40 feet, and it has a continuous and gradual ascent towards the north. Local statements as to its extent beyond Pai-namou-tjang were vague, but the plain could be seen stretching 13 miles farther up the divide of the eastern and western watersheds. Twenty miles north of this divide Mr. Carles left a similar plane last year, stretching from Anbyön to Kosan, but nearly rooo feet below the level of the present plain. There are thus three great oval fields of lava passing almost in a straight line through the mountain chain which runs from the north to the south of Corea at a height of about 1500 feet above the sea near the divide, and of 500 feet in the lower levels. There is also another plain about 4 miles wide and 12 miles long to the east in Keum-song district, the direction of which is not so well defined, but in which the depth of lava is apparently even greater than that in the others. No crater is visible in any direction to account for the enormous mass of lava; no hot springs were heard of within 30 miles, and sulphur is said to be imported from China, so that the gigantic overflow would appear to have taken place in the valley, and to have completely buried the volcano from which it came, if such were its source. At the first gold-washing visited about 270 men were said to be employed. Trenches were being dug in a bed of shingle by the river-side, and being driven parallel with the course of the stream. The men worked in parties of six, with one washer, who managed his wooden bowl very cleverly. Only small particles of gold are found, but the results seemed uniform and far superior to those of any other place visited by Mr. Carles in Corea. At two different washings which he witnessed, and which were said to give about the average yield, three basins of good earth, representing less than an hour's labour of six men, produced about fifteen pieces of gold-small indeed, but clearly visible at three yards' distance. Farther up the valley, where the men were working in smaller gangs, the yield was about the same in proportion to the number of men. On the western slope are other workings, where some 300 men are engaged, but these do not appear to be so productive. It appears that this valley has never before been worked for gold; in other places it has been sought for ages, and always found after the summer floods had brought down fresh detritus; but here the shingle seemed never to have been disturbed, or, rather, arranged in walls, before. The country here also seemed more promising than elsewhere, and to be worth the visit of an experienced miner.

For many years it was believed that the highest mountain in Sweden was Sulitjelma, on the frontier between Sweder and Norway, the height of which is about 6000 feet. A couple of years ago it was, however, discovered that the mountain of Sarjektjăkko, in Swedish Lappland, was a thousand feet higher. Lately, Dr. Svenonius, well known for his explorations of this province, has declared that neither of these mountains is the highest in Sweden, the honour belonging to Kebnekaisse, another peak in the same province, which the topographical surveyor of the province of Norrland has measured and found to be 7192 feet in height.

ACCoRDING to recent advices from the Faroe Islands, a wellknown landmark has disappeared there, viz. the rock called "the Monk," situated about five miles south of Sumbö. Its height was nearly 100 feet. On the top of it lay some large boulders, which could be seen distinctly. Already last year part of the top fell down, but the body remained until last winter or this spring, when its disappearance was discovered.

\section{MINERAL PRODUCTS OF THE UNITED STATES}

THE second Report on "The Mineral Resources of the United States," by Albert Williams, jun., Chief of the Division of Mining Statistics and Technology, United States Geological Survey, is now in press and will be issued shortly. This Report is for the calendar years 1883 and I884, and contains detailed statistics for these periods and also for preceding years, together with much descriptive and technical matter. The following are the totals of the production of the more important nineral substances in $1884:-$

Coal. - The only statistics in which the trade is interested are those relating to the amount of coal which is mined for and reaches the market. There is, besides, a local and colliery consumption which is usually disregarded in statistics, and which ranges from 5 to $6 \frac{1}{2}$ per cent. of the total shipments. Of what may be called the commercial product the quantities in 1884 were as follows:-Pennsylvania anthracite, 30,718,293 long tons; bituminous and brown coal, lignite, and small lots of anthracite mined elsewhere than in Pennsylvania, 66,875,772 long tons ; total, 97,594,065 long tons. The spot value of the commercial product was: Pennsylvania anthracite, $\$ 6 \mathrm{I}, 436,586$; bituminous and all other coals, $\$ 70,219,56 \mathrm{I}$; total, $\$ 13 \mathrm{I}, 656,147$. Including the local consumption, \&c., the total product in I884 may be stated at 106,906,295 long tons-namely, 33, 175,756 long tons of Pennsylvania anthracite and $73,730,539$ long tons of bituminous and all other coals; and the value at the mines was : Pennsylvania anthracite, $\$ 66,35 \mathrm{I}, 5 \mathrm{I} 2$; bituminous and all other coals, $\$ 77,417,066$; total, $\$ 143,768,578$. The total production (that is, including colliery and local consumption) of anthracite was $1,160,713$ long tons less than in 1883 , while its value was $\$ 10,905,543$ less, the disproportionate decline in value being due to a fall of 25 cents. per ton in "spot price $(\$ 2.25$ to $\$ 2)$. The total bituminous coal production increased $5,199,039$ long tons over that of 1883 , but its value was $\$ 4,820,734$ less, the average valuation at the collieries having fallen from $\$ I \cdot 20$ to $\mathbb{S I}_{\mathrm{I}} 05$. The total output of all coals showed a net gain in tonnage of $4,038,326$ long tons, and a decline in value of $\$ 15,726,277$.

Coke, - There were $4,873,805$ short tons of coke made in I884, worth $\$ 7,242,878$ at the ovens. This production consumed 7,951,974 short tons of coal. The amount of coke made was 590,916 tons less than in 1883 , and the value was $\$ 878,729$ less.

Petroleum.--The production of crude petroleum in 1884 was $24,089,758$ barrels of 42 gallons each, of which the Pennsylvania and New York oil-fields produced $23,622,758$ barrels. The total value, at an average spot price of 85 cents, was $\$ 20,476,294$. As compared with 1883 the production was 689,529 barrels greater; but the total value was $\$ 5,263,958$ less, the average $\mathrm{sp} t$ price having fallen from $\$ 1 \cdot 10$, or 25 cents per barrel.

Natural Gas. - The estimated value of the natural gas used in the United States in 1884 was $\$ 1,460,000$, as against $\$ 475,000$ in 1883 . The value is computed from that of the coal superseded by natural gas.

Iron. - The principal statistics for I 884 are as follows :- Iron ore mined, $8,200,000$ long tons; value at mine, $\$ 22,550,000$. Domestic iron ore consumed, 7,718,129 long tons; value at mine, $\$ 21,224,854$. Imported iron ore consumed, 487,820 long tons; total iron ore consumed, 8, I25,949 long tons. Pig iron made, $4,097,868$ long tons-a decrease of 497,642 tons as com. pared with 1883 ; value at furnace, $\$ 73,761,624$, or $\$ 18,148,576$ less than in 1883 . Total spot value of all iron and steel in the first stage of manufacture, excluding all duplications, $\$ 107,000,000$, a decline of $\$ 35,000$, 000 from I883. Fuel consumed in all iron and steel works, including blast furnaces, $1,973,305$ long tons of anthracite, 4, 226,986 long tons of bituminous coal, 3,833, I 70 long tons of coke, and $52,110,660$ bushels of charcoal, besides a notable quantity of natural gas. Limestone used as flux, $3,40 \mathrm{I}, 930$ long tons; value at quarry, $\$ 1,700,965$.

Gold and Silver.- The mint authorities estimate the production in I884 at $\$ 30,800$, 000 gold and $\$ 48,800$, o0o silver (coining rate) ; total, $\$ 79,600,000$. This was an increase of $\$ 8 \mathrm{co}, 000$ gold and $\$ 2,600,000$ silver as compared with 1883 . The gold production was equivalent to I, 489,949 troy ounces, and the silver to $37,744,605$ troy ounces.

Copper. - The production in 1884 , including $2,858,754$ pounds made from imported pyrites, was $145,221,934$ pounds, worth $\$ 17,789,687$, at an average price of $12 \frac{1}{4}$ cents per pound in New York City. The amount was $28,070, \mathbf{1} 39$ pounds greater than the production of 1883 ; but the value was $\$ 275, \mathrm{I} 20$ less than that for 1883 , owing to the decline in price. In $18844,224,000$ pounds of bluestone (sulphate of copper, "blue vitriol") were made; worth, at 4.3 cents per pound, $\$ 181,632$.

Lead.-Production, $\mathrm{I} 39,897$ short tons. Total value, at an average price of $\$ 75^{\circ} 32$ per ton on the Atlantic sea-board, \$10,537,042. The production was 4060 tons less than that of 1883, while the decrease in value was $\$ \mathbf{1}, 785,677$. The production of white lead (carbonate) is estimated at about 65,000 short tons, worth, at $4 \frac{7}{8}$ cents per pound, $\$ 6,337,500$, almost all of which was made from pig lead. The production of litharge and red lead has not been ascertained.

Zinc.-Production of metallic zinc, 38,544 short tons ; worth, at an average price of $4^{\circ} 44$ cents per pound in New York City, $\$ 3,422,707$. The output was 1672 tons greater than in 1883 , 
and the value increased $\$$ I I I,60I. Besides the spelter and sheet zinc, about 13,000 short tons of zinc white (oxide) were made directly from the ore, the total value of which, at $3 \frac{1}{3}$ cents per pound, was $\$ 910,000$.

Quicksilver. - Production, '31,913 flasks (of $76 \frac{1}{2}$ pounds net $=$ $2,44 \mathrm{I}, 344$ pounds), or 14,812 flasks less than in 1883 . Total value, at an average price of $\$ 29^{\circ} 34$ per flask at San Francisco, $\$ 936,327$, a decline of $\$ 317,305$ as compared with the total value of the product of the previous year. During the year 600,000 pounds of quicksilver vermilion were made, worth $\$ 288,000$.

Nickel.-Production of nickel contained in copper-nickel alloy, 64,550 pounds, worth, at 75 cents per pound, $\$ 48,412$; an increase of 5,750 pounds, but a decline of $\$ 508$ in total value, owing to the falling off in price.

Cobalt. - The amount of cobalt oxide made in 1884 was at:out 2000 pounds, as against 1096 pounds made in 1883 . Its value, as $\$ 2.55$ per pound was $\$ 5100$. The value of cobalt ore and matte cannot be ascertained, as it is chiefly dependent on the nickel contents.

Manganese. - The output of manganese ore in 1884 was about 10,000 long tons, or 2000 tons more than in 1883 . The total value, at $\$ 12$ per ton at the mines, was $\$ 120,000$, or about the same as in 1883 , the average price having declined $\$ 3$ per ton.

Chrominm. - The production of chrome iron ore, all from California, was about 2000 long tons, or about two-thirds as much as in 1883 . At an average value of 17.50 per ton at San Francisco, the total value was $\$ 35,000$.

Tin.-A little tin ore was taken out in the course of development work in Dakota, Wyoming, Virginia, and Alabama, but the only metallic tin made was a few hundred pounds from ore of the Black Hills (Dakota) mines, made in sample tests at New York City pending the building of reduction works at the mines.

Platinum.-The amount mined in 1884 was about 150 troy ounces, worth, crude, $\$ 3$ per ounce.

Aluminium. - The amount made in the United States in 1884 was I 800 troy ounces, an increase of 800 ounces over the production in 1883 . At 75 cents per ounce the total value was $\$ 1350$.

Building Stone.-It is estimated that the value of the building stone quarried in $\mathbf{1 8 8 4}$ was $\$ 19,000,000$, as against $\$ 20,000,000$ in -1883 , the decline being due partly to dullness of trade and partly to the increased use of other structuraI materials.

Brick and Tile.-The output was about the same as in 1883 , but as manufacturers cut down expenses still further, meeting a lower market, the total value is estimated at $\$ 30,000,000$ as against $\$ 34,000,000$ in 1883 .

Lime. - There were 37,000,000 barrels (of 200 pounds) made in 1884 , the average value per barrel at the kilns being not over 50 cents, or $\$ 18,500,000$. The production was about $5,000,000$ barrels greater than in 1883 , but owing to the fall in price the total value was about $\$ 700,000$ less.

Cement. - About roo, 000 barrels (of $400 \mathrm{lbs}$.) of artificial Portland cement were made, or Io, ooo barrels more than in 1883 ; the total value, at $\$ 2 \cdot$ Io per barrel, being $\$ 210,000$. The production of cement from natural cement rock was 3,900,000 barrels (of $300 \mathrm{lbs}$ ), or 200,000 barrels less than in 1883 ; worth, at 90 per cents per barrel, $\$ 3,510,000$. The total production of all kinds of cement was about 4,000,000 barrels, valued at $\$ 3,720,000$.

Precious Stones. - The estimated value of American precious stones sold as specimens and souvenirs in 1884 was $\$ 54,325$, and the value of the stones sold to be cut into gems was $\$ 28,650$; total, $\$ 82,975$. About $\$ 140,000$ worth of gold quartz was saved as specimens or made into jewelry and ornaments.

Buhrstones. - The value of the buhrstones yearly made in the United States is about $\$ 300,000$.

Grindstones.-Dealers estimate the value of the grindstones made in 1884 at $\$ 570,000$.

Phosphates.-The production of washed phosphate rock in South Carolina during the year ending May 3I, I884, was 431,779 long tons, worth $\$ 2,374,784$, or 53,399 tons more than in the previous year, wtth an increase of \$104,504 in value. The average spot price, $\$ 5^{\circ} 5^{\circ}$ per ton, was 50 cents less than in the preceding year. The recent discoveries of phosphate rock in the adjoining States of North Carolina, Alabama, and Florida will probably lead to a still further increase in production. Of manufactured fertilisers, 967,000 short tons, worth $26,110,000$, were made in the year ending April 30, 1884, and 1,023,500 short tons, worth $\$ 27,640$, 000, were made in the year ending April 30,1885 .

Marls. - In New Jersey about 875,000 tons, worth $\$ 437,500$ at the pits, were dug in 1884. In addition, small quantities were produced for local use in some of the Southern States. The production is declining, owing to competition with fertilisers made from phosphate rock, \&c.

Gypsum.-In the Atlantic States, from Maine to Virginia, 65,000 long tons of land plaster and 60,000 tons of stucco, total 125,000 tons, were made in I884, of which nearly all was from Nova Scotia gypsum. The statistics for Michigan have not been reported, but the production did not vary greatly from that in 1883 , in which year it was 60,082 short tons of land plaster and 159, I00 barrels (of $300 \mathrm{lbs}$.) of stucco. In Ohio 4217 short tons of land plaster and 20,307 barrels of stucco were produced. There was also a small production in other parts of the country; but the total amount of domestic gypsum used is not known.

Salt. -The production in 1884 was $6,5 \mathrm{I} 4,937$ barrels of 280 pounds (equivalent to $1,824,182,360$ pounds, or $32,574,685$ bushels, or 9I2,09I short tons, according to the unit used). The total value, computed on average wholesale prices at the

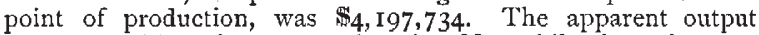
was 322,706 barrels greater than in I883, while the value was $\$$ I 3,308 less; but the production figures do not include a considerable stock on hand in the Onondaga district, not officially reported because not inspected.

Bromine. - The production is estimated at $28 \mathrm{r}, \mathbf{1 0 0}$ pounds, all from the Ohio and West Virginia salt district; worth, at 24 cents per pound, $\$ 67,464$.

Borax.-Production about 7,000,000 pounds, or 500,000 pounds more than in 1883 . The total value, however, was less than that of the product of 1883 , being about $\$ 490,000$ at San Francisco rates, as against $\$ 585,000$ in 1883 .

Sulphur. - No exact statistics. The production was only 500 tons, worth about \$ 12,000

Pyrites.-About 35,000 long tons were mined in the United States, worth about $\$ 175,000$ at the mines. Some 33,500 tons of imported pyrites were also burned, making a total consumption of 68,500 tons.

Barytes.-Full statistics not received. The production is estimated to have been about 25,000 tons; worth, at $\$ 4$ per ton, unground, at the point of production, $\$ 100,000$.

Mica. - The production of merchantable sheet mica, not including mica waste, was 147,410 pounds, valued at $\$ 368,525$.

Feldspar. - The production was 10,900 long tons, or 3200 tons less than in $\mathbf{1 8 8 3}$. IIs value at the quarries was $\$ 55$, I 12 .

Asbestos.-The amount mined was about I000 short tons, worth about $\$ 30,000$.

Graphite.-Production nominal, the supply being drawn from the stock accumulated in 1883 .

Asphaltum.-The annual production is about 3000 tons, having a spot value of $\$ 10,500$.

Alum.-About 38,000,000 pounds were made in the United States in 1884, or 3,000,000 pounds more than in 1883 . At an average spot value of $I \frac{7}{8}$ cents per pound, the product was worth $\$ 712,500$.

Copperas. - The amount made in 1884 was $15,500,000$ pounds, worth, at 60 cents per hundredweight, $\$ 93,000$.

Mineral Wattrs. - The sales of natural mineral waters in I884 amounted to $68,720,936$ gallons, valued at $\$ \Gamma, 665,490$, an apparent increase of $21,43 \mathrm{I}, 193$ gallons, and $\$ 526,007$ upon the figures for $\mathbf{1} 883$. While the sales are undoubtedly increasing, it is possible that the excess in the reported quantity and value of the waters sold in 1884 as compared with 1883 may be partly due to the greater fullness of the rcturns for 1884 . Besides the waters bottled and placed on the market there is a large local consumption, not included in the foregoing figures.

Totals - As was remarked in the former report, it is impossible to state the total mineral product in any form which, shall not be open to just criticism. It is evident that the production statistics of such incongruous substances as iron ore, metallic gold and silver, the spot value of coal mined, and the market value of metallic copper after having been transported hundreds of miles, the spot value of a crude substance like unground, unrefined barytes, and the value of a finished product like brick (in which the cost of manufacture is the leading item) cannot well be taken as items in a general summary. The statistics have been compiled with a view to giving information on those points which are of most interest and utility, and are 
presented in the form usual in the several branches of trade statistics. The result is that the values stated for the different products are necessarily taken at different stages of production or transportation, \&c. Theoretically perfect statistics of mineral products would include first of all the actual net spot value of each substance in its crudest form, as taken from the earth; and yet for practical purposes such statistics would have little interest other than the fact that the items could be combined in a grand total in which each substance should be rated on a tairly even basis. The following groupings, therefore, are presented with a full realisation of the incongruity of many of the items. The grand total might be considerably reduced by substituting the value of the iron ore mined for that of the pig iron made, by deducting the discount on silver, and by considering lime, salt, cement, borax, \&c., as manufactures. It will also be remarked that the spot values of copper, lead, zinc, and chrome iron ore are much less than their respective values after transportation to market. Still the form adopted seems to be the only one which admits of a comparison of the total values of the mineral products from year to year.

Résumé of the Values of the Metallic and Non-metallic Mineral Substances produced in the United States in 1884.

Metals

Mineral Substances named in the foregoing

Table

$\mathbb{\$}_{1} 86,097,599$

$220,007,021$

Fire-clay, kaolin, potter's clay, common brick clay, terra cotta, building sand, glass sand, limestone used as flux in lead smelting, limestone in glass making, iron ore used as flux in lead smelting, marls (other than New Jersey), gypsum, tin ore, antimony, iridosmine, mill-buhrstone, and stone for making grindstones, novaculite, corundum, lithographic stone, talc and soapstone, quartz, fluorspar, nitrate of soda, carbonate of soda, sulphate of soda, native alum, ozokerite, mineral soap, strontia, infusorial earth and tripoli, pumicestone, sienna, umber, \&c., certainly not less than

Grand Total The total value of the metals and minerals produced in 1884 was $\$ 39$, I0o, oo 8 less than in 1883 , and the decline in 1883 from I 882 was $\$ 3$, OI $2,06 \mathrm{I}$; that is, the falling off in value began on a small scale in 1883 , but was accentuated in 1884 . The net decline has been due rather to a depression in price than a decrease in quantity; indeed, several important substances show a decided increase in production, notwithstanding the general dullness of trade. The over-production, taking the whole field into consideration, has been less than was generally feared.

\section{PROF. L. SOHNCKE ON THE ORIGIN OF} THUNDERSTORM ELECTRICITY ${ }^{1}$

I $\mathrm{N}$ order to express more than mere surmises as to the origin of thunderstorm electricity we must, above all, be familiar with the atmospherical conditions under which thunderstorms usually occur. For this purpose we must first take into consideration two general facts in meteorology : first, the average decrease of temperature with increase of height in free air ; and secondly, the nature of the upper clouds.

With regard to the first point, a considerable amount of data is available in the observations of several scientific balloonists, especially those of Mr. J. Glaisher. Glaisher has constructed a table, based upon his numerous ascents, showing the average decrease of temperature for the altitudes of 1000, 2000, 3000 feet, \&c. This table shows that even in the warm summer months the temperature of the freezing-point is met with generrally at the level of between 3000 and 4000 metres (say IO, 000 to 13,000 feet).

Generally speaking, the aggregate of those points of space in which the temperature of $0^{\circ} \mathrm{C}$. prevails at any given moment must lie on a certain surface, which may be denoted as the "isothermal surface of zero C." It is of especial interest to ascertain whether the result yielded by Glaisher's ascents as to the height

'Extract from "Sitzungsberichte der Jenaischen Gesellschaft für Medecin und Naturwissenschaft." Jahrg. 2885 . Sitzung vom I Mai. of this surface in midsummer is confirmed by other ascents. In order to obtain an opinion upon this point I have grouped together those ascents which afford a sufficient number of data, in order to deduce therefrom the height of the isothermal surface of zero. This table includes twenty-three ascents by eight different balloonists at different seasons of the year; about half the ascents were made during the summer months. The following are the conclusions drawn from this table :-

In the warmest summer months the isothermal surface of zero was found to be at an height of about 3000 to 4000 metres, but occasionally sinks even at this season to about 2000 metres (siy 6500 feet) above the level of the sea. It generally rises in the course of the forenoon, and, apparently, more rapidly the nearer noon is approached. It sinks in the course of the afternoon, and, apparently, more rapidly with the greater ditance from noon. Its level may vary about 2000 metres in from one to two hours. The change from rising to sinking does not occur cxactly at noon, but perhaps one hour or even more after noon, according to season.

A knowledge of the decrease of temperature on days of thunderstorms, especially just befure the storm, presents therefore especial interest. Only few data exist on this point.

Glaisher made an ascent at 6 p.m. on the 3Ist August, I863, after a thunderstorm had taken place at $8 \mathrm{a} . \mathrm{m}$. He did no reach the isothermal surface of zero, but found a temperature of $I^{\circ} \mathrm{C}$. at a height of 2300 metres (say 7500 feet). I have never found such a low ternperature at a similar height in any of the six ascents in August and the beginning of September.

Flammarion made an ascent during the night of the thunder storm of the 14-15 July, 1868 , and met with $\mathrm{O}^{\circ} \mathrm{C}$. at a height of 2400 metres (say 6500 feet), but this was at 4 h. $26 \mathrm{~m}$. a.m. Among all the midsumwer ascents there is only one in which the isothermal surface of zero was met with at a lower level.

Welsh made an ascent in the afternoon of the r 7 th August, I 852, two hours before the occurrence of a thunderstorm; at 5 p.m. the isothermal surface of zero lay at a height of 3500 metres (say II,500 feet), but it was rapirly sinking. Welsh did not find such a rapid decrease of temperature upwards in any of his other three ascents as in this one.

Kämtz has drawn the conclusion, bașed upon the great refraction which has often been observed with sultry thunderstorm air, that the rapid change of temperature with height is an important condition for the formation of thunderstorms, especially in summer. In order to obtain more precise data upon this point I have undertaken a small meteorological investigation as to the difference of temperature existing just before thunderstorms between Freiburg in the Breisgau and the Höchenschwand in the Black Forest, 2326 feet above it. I found that in seventeen cases which were suitable for comparison, in the years 1880 and $188 \mathrm{I}$, the difference of temperature just before the thunderstorm was less than the average for the day and seas on in three cases only; in other cases it was greater.

From this it appears that, in most cases, the abnormally rapid decrease of temperature with height, and, in connection with this, the abnormally low position of the isothermal surface of zero may be taken as characteristic of the condition of weather before thunderstorms.

Secondly, attention must be paid to the nature of the upper clouds not only generally, but also more especially before thunderstorms. The clouds which lie above the isothermal surface of zero must of course mainly consist of ice particles, although, of course, the formation of clouds of superfused water particles is not excluded. The appearance of the ice clouds is, moreover, somewhat different from that of the water clouds. The former are known as "cirrus" and the latter as "cumulus" clouds. Observations or the height of clouds, made either in balloon ascents or on the ground, agree in showing that the limit of both kinds of clouds in midsummer lies about 4000 metres (say I 3,000 feet) high, which agrees pretty well with the above calculation of the level of the isothermal surface of zeru. It is not surprising, therefore, that balloonists frequently reach snow-clouds even in midsummer-for instance, Glaisher on June 26,1863 , between 3300 and 4200 metres (say I I, 000 and I 4,000 feet) ; Fonvielle on July 4, I875, at 3450 metres (say I I, 300 feet); Barral and Bixio on July 27, I850, between 4500 and 6300 metres (say 15,000 to 20,500 feet); Welsh on August 17, I850, at 5990 metres (say 19,500 feet).

While the distinction between ice and water-clouds, from their mere appearance as seen from the earth, is always somewhat difficult to be made out, we have in many cases an infallible 